\title{
Applying of arbuscular mycorrhizal fungi (AMF) and rock phosphate to wheat (Triticum aestivumL.) grown on calcareous soil and irrigated at different irrigation intervals and effect of plant growth and soil physical properties
}

\author{
Y. M. El-Edfawy*; M. M. Havey* and H. M. A. El-kotb, * \\ *Soil, Water and Environment Research Institute, Agric., Res. Center, Giza, Egypt. \\ Corresponding author: moheyharvey11@yahoo.com
}

\begin{abstract}
A field experiment was conducted along two the successive seasons of winter (2014/2015) and (2015/2016) at El-Nubaria Agricultural Experimental Station of the Agricultural Research Center (ARC), west of Alexandria, Egypt. Aim was to evaluate the effect of arbuscular mycorrhiza fungi (AMF) and rock phosphate (RP) application as well as the effect of irrigation intervals on soil properties and growth of wheat (Triticum aestivum L.) grown on sandy clay loam calcareous soil. The experiment was factorial (3 factors) with 12 treatments and three replicates. Three irrigation intervals 15, 21 and 35 days, two RP treatments non and $16 \mathrm{~kg} \mathrm{P}^{-1}$ and two AMF (non and AMF) treatments. AMF under moderate 21 day irrigation interval combined with RP was mostly effective in increasing total porosityand saturated hydraulic conductivity as well as decreasing bulk density. AMF $+\mathrm{RP}$ and irrigation every 21 days gave highest values of most growth and yield characters along with NPK content.
\end{abstract}

Keywords: mycorrhizal fungi, rockphosphate, irrigation intervals, calcareous soil and wheat plant.

\section{Introduction}

Wheat (Triticum aestivumL.) is the most important cereal crop as the main food stable for the Egyptian public. Increasing wheat productivity is a national target in Egypt to fill the gap between wheat consumption and production.Growing wheat on the newly reclaimed area of Egypt especially calcareous soil faces various problems. This soil has poor physical properties and lacks organic materials, microorganisms, macro and micronutrients.

One of the major limiting factors for plant growth is water availability in arid and semiarid regions. ElSersawy et al . (1993) reported that total porosity of calcareous soil is affected by irrigation. El-Sherbiny (2002) showed that the irrigation at 50\% depletion of available water decreased bulk density. Ghaly and El-Sodany (2009) found that three weeks irrigation intervals for Nigella sativa $L$. increasesd total porosity, hydraulic conductivity and water consumption as compared to 4 and 5 weeks intervals. Drought affects plant physiology and tends to reduce photosynthesis Munns (2002). Kumar et al. (2016) showed that AM fungi increased water holding capacity by 5 to $6 \%$ and the mean weight diameter of soil aggregate by 4 to $9 \%$. Soha and Yousef (2014) reported that yield components, oil and carotenoids contents of cress increased by irrigation upon consuming $25 \%$ of available water. El-Far and Teama (1999) studied the effect of irrigation intervals of 21,31 and 41 days on the productivity of bread and durum wheat cultivars and obtained highest number of spikes $/ \mathrm{m}^{2}, 1000$ - grain weight and grain yield by the 31- day interval. Mohsen et al. (2012) noted that maize 100 grain weight, grain weight/ear and yield decreased due to extreme drought.

Arbuscular mycorrhizal fungi (AMF) are capable of alleviating effects of drought on plant growth (Auge 2001 and Miransari 2010). Symbiotic relationship between $\mathrm{AMF}$ and plants produces colonies on the exterior part of the roots resulting in the enhanced uptake of water and nutrients (Alizadeh et al. 2011; Al-Karaki and Al-Raddad 1997; AlKaraki and Clark 1998; Sylvia et al., 1993). AMFenhance plant-water relationship through increasing stomatal resistance by adjusting plant hormonal balance and improve nutrient uptake (Elwan 2001, Harrier 2001 and Rillig and Mummey 2006). AMF causes the host plant to grow efficiently under the biotic and abiotic stress conditions (Subramanian and Charest 1997; Porcel et al., 2003 and Artursson et al., (2006).

The use of rock phosphate (RP) as a P-fertilizer has merit for areas without easy access to $\mathrm{P}$ fertilizer. Direct use of RP is more effective in acidic soils than neutral on calcareous soils (Kucey and Bole 1984). Combined application of RP with AMF can be effective (Schussler et al. 2001) and can be adopted by plants to cope with conditions of low available phosphorus (Shenoy and Kalagudi 2005; Richardson et al. 2009). Exploitation of the soil by the AMF hyphae results in high efficiency in $\mathrm{P}$ acquisition (Bucher 2007 and Smith and Read 2008). Uptake of $P$ from $R P$ increases by $A M F$ application (Cabala and Wild. 1982.; Powell 1979; and Waidyanatha et al. 1979). Boland (1994) observed increased uptake of NPK in many crops when AMF was applied. AMF improve soil structure and aggregate stability (Marshner and dell 1994). 
Hashem (1996) reported that AMF increased seed, straw yield and NPK soya beans.

\section{Materials and Methods}

A field experiment was conducted along two successive seasons of winter (2014/2015) and (2015/2016) at El-Nubaria Agricultural Experimental Station of the Agricultural Research Center (ARC), west of Alexandria in the north western coastal zone of Egypt, lying between $30^{\circ} 54^{-}$latitude and $29^{\circ} 30^{-}$ longitude and a attitude of 22 meter above sea level. The aim was evaluate the effect of arbuscular mycorrhiza fungi (AMF) and rock phosphate (RP) at different irrigation intervals on wheat ((Triticum aestivum L cv. Sakha 93) grown on a sandy clay loam calcareous soil. Main properties of soil are shown in Table 1 according to the methods described by Page et al. (1982) and Klute (1986).

The experimental design was a randomized complete block. There were 12 treatments carried out in split - plot design with three replicates. The experiment included 3 factors as follows: (1) irrigation intervals: three of evry 15 days $\left(\mathrm{I}_{1}\right), 21$ days $\left(\mathrm{I}_{2}\right)$ and 35 days $\left(\mathrm{I}_{3}\right)$ days (main plot); (2) rock-P: two treatments i.e no- $\mathrm{P}\left(\mathrm{P}_{0}\right)$ and $16 \mathrm{~kg} \mathrm{P} \mathrm{ha}^{-1}\left(\mathrm{P}_{1}\right)$ and (3) two mycorrhizal treatments: non $\left(\mathrm{M}_{0}\right)$ and inoculation $\left(\mathrm{M}_{1}\right)$. Treatments of $\mathrm{P}$ and $\mathrm{M}$ were randomized as subplots.

Rock phosphate was added during soil preparation before planting. $\mathrm{N}$ and $\mathrm{K}$ rats of $250 \mathrm{~kg} \mathrm{~N}+120 \mathrm{~kg} \mathrm{~K}$ $\mathrm{ha}^{-1}$ were added to all plots. $\mathrm{N}$ was as urea (460 $\mathrm{g} \mathrm{N}$ $\mathrm{kg}^{-1}$ ) added in 2 equal doses, before the first and second irrigation, and $\mathrm{K}$ was as potassium sulphate $\left(400 \mathrm{~g} \mathrm{~K} \mathrm{~kg}^{-1}\right)$ was given before the first irrigation. Ten plants from each plot were taken randomly dried and kept for analyses. Grain and straw samples were taken. Analyses of soil and plant samples were done using methods cited by (Chapman and Pratt 1961; Jackson 1973; Page et al. 1982 and Klute (1986).

Table 1. Main characteristics of soil of the experiment.

\begin{tabular}{|c|c|c|c|c|}
\hline \multicolumn{2}{|c|}{ Soil depth $(\mathrm{cm})$} & $0-10$ & $10-20$ & $20-30$ \\
\hline \multicolumn{5}{|c|}{ Physical properties } \\
\hline \multirow{4}{*}{$\begin{array}{l}\text { Particle size } \\
\text { distribution } \%\end{array}$} & Coarse sand & 2.46 & 2.35 & 2.07 \\
\hline & Fine sand & 49.82 & 38.12 & 50.41 \\
\hline & Silt & 20.53 & 26.03 & 22.22 \\
\hline & Clay & 27.19 & 33.50 & 25.30 \\
\hline \multicolumn{2}{|l|}{ Texture class } & sandy clay loam & sandy clay loam & sandy clay loam \\
\hline \multicolumn{2}{|c|}{ Bulk density $\left(\mathrm{Mgm}^{-3}\right)$} & 1.44 & 1.48 & 1.57 \\
\hline \multicolumn{2}{|c|}{ Total porosity $(\%)$} & 42.17 & 41.96 & 39.85 \\
\hline \multicolumn{2}{|c|}{$\begin{array}{l}\text { Saturated hydraulic conductivity } \\
\left(\mathrm{cm} \mathrm{h}^{-1}\right)\end{array}$} & 2.41 & 2.36 & 2.12 \\
\hline \multicolumn{5}{|c|}{ Chemical properties } \\
\hline \multicolumn{2}{|c|}{$\mathrm{CaCO}_{3}\left(\mathrm{~g} \mathrm{~kg}^{-1}\right)$} & 286.6 & 313.2 & 310.7 \\
\hline \multicolumn{2}{|c|}{ Organic matter $\left(\mathrm{g} \mathrm{kg}^{-1}\right)$} & 6.1 & 9.6 & 5.3 \\
\hline \multicolumn{2}{|c|}{$\mathrm{pH}^{* *}$} & 7.79 & 7.81 & 7.80 \\
\hline \multicolumn{2}{|l|}{$\mathrm{EC}\left(\mathrm{dSm}^{-1}\right)^{* *}$} & 2.03 & 1.05 & 1.30 \\
\hline \multirow{4}{*}{$\begin{array}{l}\text { Soluble anions } \\
\text { mmol }_{\mathrm{c}} \mathrm{L}^{-1}\end{array}$} & $\mathrm{HCO}_{3}^{-}$ & 1.47 & 0.32 & 1.48 \\
\hline & $\mathrm{Cl}^{-}$ & 5.86 & 3.09 & 3.29 \\
\hline & $\mathrm{SO}_{4}^{2-}$ & 5.63 & 3.29 & 3.53 \\
\hline & $\mathrm{CO}_{3}{ }^{2-}$ & 0.00 & 0.00 & 0.00 \\
\hline \multirow{4}{*}{$\begin{array}{l}\text { Soluble cations } \\
\mathrm{mmol}_{\mathrm{c}} \mathrm{L}^{-1}\end{array}$} & $\mathrm{Ca}^{2+}$ & 2.05 & 2.82 & 1.03 \\
\hline & $\mathrm{Mg}^{2+}$ & 2.11 & 2.89 & 1.67 \\
\hline & $\mathrm{Na}^{+}$ & 7.80 & 0.73 & 5.00 \\
\hline & $\mathrm{K}^{+}$ & 1.00 & 0.30 & 0.80 \\
\hline
\end{tabular}

*According to the USDA soil Texture triangle

** $\mathrm{pH}$ of $1: 2.5$ soil : water, EC: of past extract 


\section{Results and Discussion}

\section{Soil physical properties}

Results of Table 2 show that the soil physical properties were affected mainly by inoculation with arbuscular mycorrhizal fungi

\subsection{Soil bulk density}

Data in Table 2 show that the soil bulk density (BD) were significantly decreased under AMF treated plots $\left(\mathrm{M}_{1}\right)$ compared with untreated plots $\left(\mathrm{M}_{0}\right)$. The effect was more pronounced in the top soil layer $(0$ $10 \mathrm{~cm}$ ). Average decreases were 4.87, 2.55 and 2.21 $\%$ for the soil depths of $0-10,10-20$ and $20-30 \mathrm{~cm}$, respectively. This shows that mycorrhizal network around the plant roots causes maiked positive effect on BD (Karandashov and Bucher 2005; Zaki and Radwan 2006; Smith and Read 2008; El-Sherbiny 2002 and Harvey et al. 2015).

Concerning the main effect of rock phosphate (RP) treatments on soil bulk density, data reveal that RP results had no significant effect in bulk density. (Sultani et al. 2007 and El-Maddah et al. 2012) found that phosphorus application did not affect bulk density.

BD significantly increased by increasing irrigation intervals. Average values for the $0-10 \mathrm{~cm}$ layer were $1.31,1.27$ and $1.33 \mathrm{Mg} \mathrm{m}^{-3}$ for irrigation interval 15, 21 and 35 days, respectively, corresponding values for the $10-20 \mathrm{~cm}$ layer were $1.36,1.33$ and 1.37 respectively, and those for the $20-30 \mathrm{~cm}$ layer were 1.43, 1.38 and $1.44 \mathrm{Mg} \mathrm{m}^{-3}$, respectively. These findings agree with those obtained by (Ghaly and ElSodany 2009; El-Maddah et al., 2012 and Harvey 2012). The lowest BD $\left(1.21 \mathrm{Mg} \mathrm{m}^{-3}\right)$ with that of the $0-10 \mathrm{~cm}$ depth under 21 day irrigation interval treated with RP +AMF.

\subsection{Soil total porosity}

Table 2 shows that AMF increased the percentage of total porosity (TP). Average values were 46.38 and $49.00 \%$ for $\mathrm{M}_{0}$ and $\mathrm{M}_{1}$, respectively at the depth of $0-10 \mathrm{~cm}$ with an average increase of $5.6 \%$. Regarding the $10-20 \mathrm{~cm}$ depth the increase was $3.0 \%$ while the $20-30 \mathrm{~cm}$ the increase was $2.8 \%$. These illustrate the positive effect of the AMF hyphae increasing aggregation of soil particles (Wilson $\boldsymbol{e t}$ al., 2009 and Singh et al., 2009). Harvey et al. (2015) stated that AMF decreased BDand increased total porosity.

Increasing the irrigation intervals from 15 to 35 days increased TP.While the increase to 21 days caused no significant change. Average TP values in the $0-10 \mathrm{~cm}$ layer for the 15,21 and 35 - day The main effect of irrigation intervals were $47.59,49.00$ and 46.49, respectively .corresponding values of the $10-20 \mathrm{~cm}$ were 46.67, 47.65 and $46.08 \%$ respectively. Corresponding values for the $20-30 \mathrm{~cm}$ were $44.36,46.50$ and $43.97 \%$, respectively. Soil aggregation was reported to increase by short irrigation intervals (Sersawy et al. 1993; ElMaghraby 1997; El-Sherbiny 2002 and Harvey 2012).

\section{1-3-Saturated hydraulic conductivity}

As soil bulk density decreases the total pore space increases and consequently influence soil hydraulic properties, e.g. saturated hydraulic conductivity, infiltration rate and the related transport processes. Data in Table 2 revealed that at all layers the inoculation with $\operatorname{AMF}\left(M_{1}\right)$ increased significantly the values of saturated hydraulic conductivity ( $\left.\mathrm{K}_{\text {sat }}\right)$ compared with un-inoculated $\left(\mathrm{M}_{0}\right)$ plots. The main effect of AMF at the depth of $0-10 \mathrm{~cm}$ the values of $\mathrm{K}_{\text {sat }}$ were 5.09 and $5.47 \mathrm{~cm} \mathrm{~h}^{-1}$ for treatments $\mathrm{M}_{0}$ and $\mathrm{M}_{1}$, respectively with increasing percentage of $7.5 \%$ whereas, at the second depth recorded 4.39 and 4.86 $\mathrm{cm} \mathrm{h}{ }^{-1}$ for $\mathrm{M}_{0}$ and $\mathrm{M}_{1}$, respectively with increment percentage of $10.7 \%$ and at the third layer recorded 3.35 and $3.65 \mathrm{~cm} \mathrm{~h}^{-1}$ for $\mathrm{M}_{0}$ and $\mathrm{M}_{1}$, respectively with percentage of $9 \%$. These results may be due to the effect of AMF hyphae on soil structure (Smith and Read 2008; Singh et al., 2009 and Harvey et al., 2015).

Concerning the effect of irrigation intervals on $\mathrm{K}_{\text {sat }}$ data in Table 2 indicated that irrigation interval every 21 days $\left(\mathrm{I}_{2}\right)$ was of greater effect on $\mathrm{K}_{\text {sat }}$ than the $\left(\mathrm{I}_{1}\right)$ and $\left(\mathrm{I}_{3}\right)$. The main effect of irrigation intervals at the top soil layer were $5.29,5.33$ and $5.21 \mathrm{~cm} \mathrm{~h}^{-1}$ for $\left(\mathrm{I}_{1}\right),\left(\mathrm{I}_{2}\right)$ and $\left(\mathrm{I}_{3}\right)$ respectively. While it decreased 4.62, 4.68 and $4.57 \mathrm{~cm} \mathrm{~h}^{-1}$ at the second soil layer (10-20 $\mathrm{cm})$ the decreased at the third soil layer $(20-30 \mathrm{~cm})$ to $3.5,3.53$ and $3.47 \mathrm{~cm} \mathrm{~h}^{-1}$ under $\mathrm{I}_{1}, \mathrm{I}_{2}$ and $\mathrm{I}_{3}$, respectively. The obtained results can be attributed to the short irrigation intervals induced the formation of water stable aggregates, while long one destroyed it and hence increased micropores which led to increase hydraulic conductivity as compared to the short one. These conclusions stand in well agreement with those reported by (Aziz et al., 1999; El-Sherbiny 2002 and Harvey 2012).

From the previous discussion, it can deduced, in general, the inoculated plants $\left(\mathrm{M}_{1}\right)$ under moderate soil moisture level $\left(I_{2}\right)$ combined with the rock phosphate treatment $\left(\mathrm{RP}_{1}\right)$ was the mostly effective in increases the values of total porosity and saturated hydraulic conductivity as well as decreases the values of bulk density significantly compare with untreated plots and with other treatments. 
Table 2. Soil physical properties as affectecdby mycorrhizal fungi and rock phosphate under irrigation intervals

\begin{tabular}{|c|c|c|c|c|c|c|c|c|c|c|}
\hline \multirow{3}{*}{$\begin{array}{l}\text { irrigation } \\
\text { intervals } \\
\text { (I) }\end{array}$} & \multirow{3}{*}{$\begin{array}{c}\text { Rock } \\
\text { phosphate } \\
\text { (RP) }\end{array}$} & \multicolumn{9}{|c|}{ Mycorrhizal (M) } \\
\hline & & $\mathrm{M}_{0}$ & $\mathrm{M}_{1}$ & mean & $\mathrm{M}_{2}$ & $\mathrm{M}_{3}$ & mean & $\mathrm{M}_{2}$ & $\mathrm{M}_{3}$ & mean \\
\hline & & \multicolumn{3}{|c|}{ Bulk density (Mgm-3) } & \multicolumn{3}{|c|}{ Total porosity (\%) } & \multicolumn{3}{|c|}{$\begin{array}{l}\text { Saturated hydraulic } \\
\text { conductivity } \mathrm{cm} \mathrm{h}^{-1}\end{array}$} \\
\hline \multicolumn{11}{|c|}{$0-10 \mathrm{~cm}$} \\
\hline \multirow{2}{*}{$\mathrm{I}_{1}$} & $\mathrm{RP}_{0}$ & 1.34 & 1.27 & 1.31 & 46.18 & 49.00 & 47.59 & 5.13 & 5.45 & 5.29 \\
\hline & $\mathrm{RP}_{1}$ & 1.35 & 1.26 & 1.31 & 45.78 & 49.40 & 47.59 & 5.12 & 5.47 & 5.30 \\
\hline \multicolumn{2}{|c|}{ Mean } & 1.35 & 1.27 & 1.31 & 45.98 & 49.20 & 47.59 & 5.13 & 5.46 & 5.29 \\
\hline \multirow{2}{*}{$\mathrm{I}_{2}$} & $\mathrm{RP}_{0}$ & 1.32 & 1.24 & 1.28 & 46.99 & 50.20 & 48.59 & 5.14 & 5.49 & 5.32 \\
\hline & $\mathrm{RP}_{1}$ & 1.31 & 1.21 & 1.26 & 47.39 & 51.41 & 49.40 & 5.21 & 5.47 & 5.34 \\
\hline \multicolumn{2}{|c|}{ Mean } & 1.32 & 1.23 & 1.27 & 47.19 & 50.80 & 49.00 & 5.18 & 5.48 & 5.33 \\
\hline \multirow{2}{*}{$\mathrm{I}_{3}$} & $\mathrm{RP}_{0}$ & 1.35 & 1.31 & 1.33 & 45.78 & 47.39 & 46.59 & 4.95 & 5.44 & 5.20 \\
\hline & $\mathrm{RP}_{1}$ & 1.34 & 1.33 & 1.34 & 46.18 & 46.59 & 46.39 & 4.96 & 5.47 & 5.22 \\
\hline \multicolumn{2}{|c|}{ Mean } & 1.35 & 1.32 & 1.33 & 45.98 & 46.99 & 46.49 & 4.96 & 5.46 & 5.21 \\
\hline \multirow{2}{*}{\multicolumn{2}{|c|}{ Grand mean }} & 1.34 & 1.27 & 1.30 & 46.39 & 49.00 & 47.69 & 5.09 & 5.47 & 5.28 \\
\hline & & \multicolumn{9}{|c|}{ Means of RP Treatments } \\
\hline \multicolumn{2}{|c|}{$\mathrm{RP}_{0}$} & 1.34 & 1.27 & 1.31 & 46.32 & 48.86 & 47.59 & 5.07 & 5.46 & 5.27 \\
\hline \multicolumn{2}{|c|}{$\mathrm{RP}_{1}$} & 1.33 & 1.27 & 1.30 & 46.45 & 49.13 & 47.79 & 5.10 & 5.47 & 5.28 \\
\hline \multirow{4}{*}{\multicolumn{2}{|c|}{ L.S.D 0.05}} & \multicolumn{3}{|c|}{ I: 0.01 RP: n.s M: 0.01} & \multicolumn{3}{|c|}{ I: 1.51 RP: n.s M: 1.94 I } & \multicolumn{3}{|c|}{ I: 0.09 RP: n.s M: 0.11} \\
\hline & & \multicolumn{3}{|c|}{ I*PR: n.s I*M: 0.02} & \multicolumn{3}{|c|}{ I* PR: n.s I*M: 1.07} & \multicolumn{3}{|c|}{ I*PR: n.s I*M: 0.26} \\
\hline & & \multicolumn{3}{|c|}{$\mathrm{RP} * \mathrm{M}: 0.02$} & \multicolumn{3}{|c|}{$\mathrm{RP} * \mathrm{M}: 1.15$} & \multicolumn{3}{|c|}{$\mathrm{RP} * \mathrm{M}: 0.16$} \\
\hline & & \multicolumn{3}{|c|}{$\mathrm{I} * \mathrm{RP} * \mathrm{M}: 0.04$} & \multicolumn{3}{|c|}{$\mathrm{I} * \mathrm{RP} * \mathrm{M}: 2.77$} & \multicolumn{3}{|c|}{$\mathrm{I} * \mathrm{RP} * \mathrm{M}: 0.34$} \\
\hline
\end{tabular}

\begin{tabular}{|c|c|c|c|c|c|c|c|c|c|c|}
\hline \multicolumn{11}{|c|}{$10-20 \mathrm{~cm}$} \\
\hline \multirow{2}{*}{$\mathrm{I}_{1}$} & $\mathrm{RP}_{0}$ & 1.38 & 1.35 & 1.37 & 45.49 & 47.06 & 46.27 & 4.37 & 4.87 & 4.62 \\
\hline & $\mathrm{RP}_{1}$ & 1.39 & 1.32 & 1.36 & 45.88 & 48.24 & 47.06 & 4.44 & 4.81 & 4.63 \\
\hline \multicolumn{2}{|c|}{ Mean } & 1.39 & 1.34 & 1.36 & 45.69 & 47.65 & 46.67 & 4.41 & 4.84 & 4.62 \\
\hline \multirow{2}{*}{$\mathrm{I}_{2}$} & $\mathrm{RP}_{0}$ & 1.36 & 1.32 & 1.34 & 47.06 & 48.63 & 47.84 & 4.41 & 4.89 & 4.65 \\
\hline & $\mathrm{RP}_{1}$ & 1.35 & 1.33 & 1.34 & 47.67 & 48.24 & 47.95 & 4.47 & 4.94 & 4.71 \\
\hline \multicolumn{2}{|c|}{ Mean } & 1.36 & 1.33 & 1.34 & 47.36 & 48.43 & 47.90 & 4.44 & 4.92 & 4.68 \\
\hline \multirow{2}{*}{$\mathrm{I}_{3}$} & $\mathrm{RP}_{0}$ & 1.38 & 1.35 & 1.37 & 45.49 & 47.06 & 46.27 & 4.33 & 4.76 & 4.55 \\
\hline & $\mathrm{RP}_{1}$ & 1.39 & 1.37 & 1.38 & 45.49 & 46.27 & 45.88 & 4.34 & 4.86 & 4.60 \\
\hline \multicolumn{2}{|c|}{ Mean } & 1.39 & 1.36 & 1.37 & 45.49 & 46.67 & 46.08 & 4.34 & 4.81 & 4.57 \\
\hline \multicolumn{2}{|c|}{ Grand mean } & 1.38 & 1.34 & 1.36 & 46.18 & 47.58 & 46.88 & 4.39 & 4.86 & 4.62 \\
\hline & & \multicolumn{9}{|c|}{ Means of RP Treatments } \\
\hline \multicolumn{2}{|c|}{$\mathrm{RP}_{0}$} & 1.37 & 1.34 & 1.36 & 46.01 & 47.58 & 46.80 & 4.37 & 4.84 & 4.61 \\
\hline \multicolumn{2}{|c|}{$\mathrm{RP}_{1}$} & 1.38 & 1.34 & 1.36 & 46.35 & 47.58 & 46.96 & 4.42 & 4.87 & 4.64 \\
\hline \multicolumn{2}{|c|}{ L.S.D 0.05} & $\begin{array}{l}\text { I: } 0.01 \\
0.01 \\
\text { n.s I* } \\
0.03 \quad \mathrm{I}\end{array}$ & $\begin{array}{l}\text { RP: n.s } \\
\text { 1: } 0.03 \mathrm{RH} \\
\text { RP*M: } 0\end{array}$ & $\begin{array}{l}\text { M: } \\
\text { I*PR: } \\
\text { P* } \\
04\end{array}$ & \multicolumn{3}{|c|}{$\begin{array}{l}\text { I: } 1.11 \quad \text { RP: n.s M: } 1.25 \\
\text { I*PR: n.s I*M: } 1.67 \\
\text { RP*M:1.43 I*RP*M:1.38 }\end{array}$} & $\begin{array}{l}\text { I: } 0.01 \\
0.25 \\
\text { n.s I*I } \\
\mathrm{I}^{*} \mathrm{RP} * \mathrm{I}\end{array}$ & $\begin{array}{l}\text { RP: n.s } \\
\text { M: } 0.4 \mathrm{RP} \\
\text { M: } 0.49 \\
\end{array}$ & $\begin{array}{c}\text { M: } \\
\text { I*PR: } \\
* \text { M: n.s } \\
\end{array}$ \\
\hline \multicolumn{11}{|c|}{$20-30 \mathrm{~cm}$} \\
\hline \multirow{2}{*}{$\mathrm{I}_{1}$} & $\mathrm{RP}_{0}$ & 1.44 & 1.41 & 1.43 & 43.58 & 45.14 & 44.36 & 3.34 & 3.63 & 3.49 \\
\hline & $\mathrm{RP}_{1}$ & 1.45 & 1.42 & 1.44 & 43.97 & 44.75 & 44.36 & 3.39 & 3.65 & 3.52 \\
\hline \multicolumn{2}{|c|}{ Mean } & 1.45 & 1.42 & 1.43 & 43.78 & 44.94 & 44.36 & 3.37 & 3.64 & 3.50 \\
\hline \multirow{2}{*}{$\mathrm{I}_{2}$} & $\mathrm{RP}_{0}$ & 1.40 & 1.37 & 1.39 & 45.81 & 47.08 & 46.45 & 3.35 & 3.70 & 3.53 \\
\hline & $\mathrm{RP}_{1}$ & 1.39 & 1.35 & 1.37 & 45.91 & 47.08 & 46.50 & 3.37 & 3.71 & 3.54 \\
\hline \multicolumn{2}{|c|}{ Mean } & 1.40 & 1.36 & 1.38 & 45.86 & 47.08 & 46.47 & 3.36 & 3.71 & 3.53 \\
\hline \multirow{2}{*}{$\mathrm{I}_{3}$} & $\mathrm{RP}_{0}$ & 1.46 & 1.42 & 1.44 & 43.19 & 44.75 & 43.97 & 3.33 & 3.59 & 3.46 \\
\hline & $\mathrm{RP}_{1}$ & 1.45 & 1.43 & 1.44 & 43.58 & 44.80 & 44.19 & 3.34 & 3.61 & 3.48 \\
\hline \multicolumn{2}{|c|}{ Mean } & 1.46 & 1.43 & 1.44 & 43.39 & 44.77 & 44.08 & 3.34 & 3.60 & 3.47 \\
\hline \multirow{2}{*}{\multicolumn{2}{|c|}{ Grand mean }} & 1.43 & 1.40 & 1.42 & 44.34 & 45.60 & 44.97 & 3.35 & 3.65 & 3.50 \\
\hline & & \multicolumn{9}{|c|}{ Means of RP Treatments } \\
\hline \multicolumn{2}{|c|}{$\mathrm{RP}_{0}$} & 1.43 & 1.40 & 1.42 & 44.19 & 45.65 & 44.92 & 3.34 & 3.64 & 3.49 \\
\hline \multicolumn{2}{|c|}{$\mathrm{RP}_{1}$} & 1.43 & 1.40 & 1.42 & 44.49 & 45.54 & 45.02 & 3.37 & 3.66 & 3.51 \\
\hline \multicolumn{2}{|c|}{ L.S.D 0.05} & $\begin{array}{l}\text { I: } 0.06 \\
0.02 \\
\text { n.s I*I } \\
\text { n.s I* }\end{array}$ & $\begin{array}{l}\text { RP: n.s } \\
\text { I: } 0.03 \mathrm{R} \\
\mathrm{P} * \mathrm{M}: \mathrm{n} .\end{array}$ & $\begin{array}{l}\text { M: } \\
\text { I*PR: } \\
\text { P*M: }\end{array}$ & \multicolumn{3}{|c|}{$\begin{array}{l}\text { I: } 2.18 \text { RP: n.s M: } 0.95 \\
\text { I*PR: n.s I*M: } 2.06 \text { RP*M: } \\
\text { n.s } \quad \text { I*RP*M: n.s }\end{array}$} & $\begin{array}{l}\text { I: } 0.04 \\
0.17 \\
\text { n.s I*I } \\
\text { n.s }\end{array}$ & $\begin{array}{l}\text { RP: n.s } \\
\text { I: } 2,66 \mathrm{RI} \\
\text { I*RP*M: }\end{array}$ & $\begin{array}{l}\text { M: } \\
\text { I*PR: } \\
\text { P*M: } \\
\text { n.s }\end{array}$ \\
\hline
\end{tabular}

Notes: $\mathrm{I}_{1}, \mathrm{I}_{2}$ and $\mathrm{I}_{3}$ : irrigation every 15,21 and 35 days respectively; $\mathrm{RP}_{0}$ and $\mathrm{RP}_{1}$ : non and $16 \mathrm{~kg} \mathrm{P} \mathrm{ha}^{-1} ; \mathrm{M} 0$ and $\mathrm{M} 1$ : non and AMF n.s: non-significant at the $5 \%$ levels of probability at L.S.D test. 
2. Plant growth and yield characters as affectecd by mycorrhizal fungi and rock phosphate under irrigation intervals:

Results in Tables 3 indicate that application of RP combined with AMF with irrigation at 21-day interval gave highest positive effects. Lowest values of plant growth attributes 89.10, 14.90, 5.90, 4.90 and 5.01 for plant height, shoot dry weight plant $^{-1}$, No. of spike plant $^{-1}$, dry weight of spike plant ${ }^{-1}$, weight of 100 grain, respectively. While highest values 96.80, 16.20, 7.60, 7.30 and 6.02, respectively were obtained by AMF-RP treated plant with irrigation at 21-day interval.

As regard to RP effect, the data shows that all yield characters were increased as affected by $\mathrm{RP}_{1}$ treatment compare with $\mathrm{RP}_{0}$. The percentage of increaments were 8.29, 12.17, 24.18, 29.67 and 16.11 $\%$ for plant height, shoot dry weight plant $^{-1}$, No. of spike plant ${ }^{-1}$, dry weight of spike plant ${ }^{-1}$ and weight of 100 grain, respectively.

Regarding AMF and RP, Plant growth and yield characters were affected significantly by irrigation intervals. Data in Table 3 shows that the irrigation every 21 days is recorded the highest values of all charactersas compare with the other two irrigation intervals (15 and 35 days).

The using of rock phosphate application and inoculation with mycorrhizal fungi gave values higher than untrated plots of all yield characters under all irrigation intervals. These increase might be due to the high efficiency of mycorrhizal fungi in mobilizing the fixed form in rock phosphate, moreover, it may be due to its production of growth promoting substances and organic acids which resulted in the availability of $\mathrm{P}$ and thus supplying the growing plants with their phosphorous requirements which reflecting the increases nutrient uptake and consequently enhance growth and yield for wheat plant in calcareous soils. These results are in harmony with those obtained by (Alizadeh et al., 2011; Ghorbanian et al., 2011; Arab et al., 2013; Gomaa et al., 2015 and Aissaet al., 2016) who reported that the uptake of phosphorous was influenced by inoculation with mycorrhizal fungi under water stress in calcareous soil.

The inoculation with $\operatorname{AMF}\left(\mathrm{M}_{1}\right)$ combined with application of rock phosphate $\left(\mathrm{RP}_{1}\right)$ under the irrigation every 21 days $\left(\mathrm{I}_{2}\right)$ give positive and significant increase in plant growth and yield characters of wheat plant.The mean values were 102.1, 16.8, 9.7, 7.8 and 6.2 for plant height, shoot dry weight plant $^{-1}$, No. of spike plant ${ }^{-1}$, dry weight of spike plant ${ }^{-1}$, weight of 100 grain, respectively.

\section{3-Wheat yield as affected by mycorrhizal fungi and rock phosphate under irrigation intervals \\ Data in Table 4 show that grain, straw, grain + straw and harvest index (HI) were significantly increased by AMF with irrigation at 21-day interval lowest values were given by the non-AMF, non RP}

treatment irrigated at 35-day interval. Highest values were given by the AMF + RP treatment irrigated at 21-day interval. AMF gave average increases of 12.4, $11.0,11.5$ and $0.9 \%$ for yields of grain, straw, grain + straw and HI respectively. Corresponding average increases due to RP were 17.0, 14.3, 15.2 and $1.1 \%$ respectively. Irrigation every 21 days gave highest values $4010.76,70.87$, and $11097.90 \mathrm{~kg} \mathrm{ha}^{-1}$ for grain, straw, grain + straw, respectively while irrigation every 35 days gave lowest values (1925.04, 5655.54 and $7580 . .58$, respectively).

\section{4- NPK contents as affected by mycorrhizal fungi} and rock phosphate under irrigation intervals:

Data in Table 5 show that NPK contents were significantly increased by AMF with irrigation at 21day interval lowest values were given by the nonAMF, non RP treatment irrigated at 35-day interval. Highest values were given by the AMF + RP treatment irrigated at 21-day interval. AMF gave average increases of 3.6, 9.8 and $15.0 \%$ for $\mathrm{N}, \mathrm{P}$ and $\mathrm{K}$ respectively for grain while in straw 5.3, 9.3 and 4.0 respectively. Corresponding average increases due to RP were 5.6, 15.8 and $26.0 \%$ respectively. Irrigation every 21 days gave highest values $2.36,0.32$ and 0.61 $\%$ for N, P and K, respictively for grain and 1.03, 0.26 and 1,46 respectively for straw while irrigation every 35 days gave lowest values $1.86,0.17$ and $0.20 \%$ respectively for grain while for straw $0.74,0.19$ and $1,08 \%$ respectively. These results were well in agreement with those reported by (Marchner and dell 1994; Boland 1994; Grant et al., 2004; Arab et al., 2013; Gomaa et al., 2015 and Aissa et al., 2016). Who reported that inoculated plants with arbusular mycorrhizal fungi (AMF) and rock phosphate application increases total NPK contents in seed and straw for many crops.

\section{conclusions}

Generally, irrigation every 21 days and rock phosphate application as well as inoculation with mycorrhizal effective in increases the values of total porosity and saturated hydraulic conductivity as well as decreases the values of bulk density and procured the highest yield of growing crop, yield characters and components and its contents of NPK. In addition inoculated plants with AMF improved resistance of wheat plant to drought stress and compensate some of the effect of the drought stress. 
Table 3. Plant growth and yield characters as affected by mycorrhizal fungi and rock phosphate under irrigation intervals.

\begin{tabular}{|c|c|c|c|c|c|c|c|c|c|c|c|c|c|c|c|c|}
\hline \multirow{3}{*}{$\begin{array}{l}\text { Irrigation } \\
\text { intervals } \\
\text { (I) }\end{array}$} & \multirow{3}{*}{$\begin{array}{l}\text { Rock } \\
\text { phosphate } \\
\text { (RP) }\end{array}$} & \multicolumn{15}{|c|}{ Mycorrhizal (M) } \\
\hline & & $\mathrm{M}_{0}$ & $\mathrm{M}_{1}$ & mean & $\mathrm{M}_{2}$ & $\mathrm{M}_{3}$ & mean & $\mathrm{M}_{2}$ & $\mathrm{M}_{3}$ & mean & $\mathrm{M}_{2}$ & $\mathrm{M}_{3}$ & mean & $\mathrm{M}_{2}$ & $\mathrm{M}_{3}$ & mean \\
\hline & & \multicolumn{3}{|c|}{ Plant height $(\mathrm{cm})$} & \multicolumn{3}{|c|}{$\begin{array}{l}\text { Dry weigh of shoot } \\
\text { plant }^{-1}(\mathrm{~g})\end{array}$} & \multicolumn{3}{|c|}{ No. of spike plant ${ }^{-1}$} & \multicolumn{3}{|c|}{$\begin{array}{c}\text { Dry weight of spike } \\
\text { Plant }^{-1}(\mathrm{~g})\end{array}$} & \multicolumn{3}{|c|}{$\begin{array}{l}\text { Weight of } 100 \text { grain } \\
(\mathrm{g})\end{array}$} \\
\hline \multirow{2}{*}{$\mathrm{I}_{1}$} & $\mathrm{RP}_{0}$ & 89.10 & 91.80 & 90.45 & 14.90 & 15.10 & 15.00 & 5.90 & 6.40 & 6.15 & 4.90 & 5.50 & 5.20 & 5.01 & 5.39 & 5.20 \\
\hline & $\mathrm{RP}_{1}$ & 93.60 & 96.80 & 95.20 & 15.80 & 16.20 & 16.00 & 7.10 & 7.60 & 7.35 & 6.60 & 7.30 & 6.95 & 5.61 & 6.02 & 5.82 \\
\hline \multicolumn{2}{|c|}{ Mean } & 91.35 & 94.30 & 92.83 & 15.35 & 15.65 & 15.50 & 6.50 & 7.00 & 6.75 & 5.75 & 6.40 & 6.08 & 5.31 & 5.71 & 5.51 \\
\hline \multirow{2}{*}{$\mathrm{I}_{2}$} & $\mathrm{RP}_{0}$ & 97.00 & 97.90 & 97.45 & 15.30 & 15.90 & 15.60 & 7.20 & 7.80 & 7.50 & 5.84 & 6.51 & 6.18 & 5.12 & 5.51 & 5.32 \\
\hline & $\mathrm{RP}_{1}$ & 99.30 & 102.10 & 100.70 & 16.10 & 16.80 & 16.45 & 8.20 & 9.70 & 8.95 & 6.97 & 7.80 & 7.39 & 6.13 & 6.20 & 6.17 \\
\hline \multicolumn{2}{|c|}{ Mean } & 98.15 & 100.00 & 99.08 & 15.70 & 16.35 & 16.03 & 7.70 & 8.75 & 8.23 & 6.41 & 7.16 & 6.78 & 5.63 & 5.86 & 5.74 \\
\hline \multirow{2}{*}{$\mathrm{I}_{3}$} & $\mathrm{RP}_{0}$ & 70.20 & 76.50 & 73.35 & 9.10 & 9.80 & 9.45 & 4.30 & 5.00 & 4.65 & 3.30 & 3.80 & 3.55 & 4.17 & 4.39 & 4.28 \\
\hline & $\mathrm{RP}_{1}$ & 79.30 & 84.70 & 82.00 & 10.90 & 11.80 & 11.35 & 5.60 & 6.00 & 5.80 & 4.30 & 4.70 & 4.50 & 4.78 & 4.81 & 4.80 \\
\hline \multicolumn{2}{|c|}{ Mean } & 74.75 & 80.60 & 77.68 & 10.00 & 10.80 & 10.40 & 4.95 & 5.50 & 5.23 & 3.80 & 4.25 & 4.03 & 4.48 & 4.60 & 4.54 \\
\hline \multicolumn{2}{|c|}{ Grand mean } & 88.08 & 91.63 & 89.86 & 13.68 & 14.27 & 13.98 & 6.38 & 7.08 & 6.73 & 5.32 & 5.94 & 5.63 & 5.14 & 5.39 & 5.26 \\
\hline & & \multicolumn{15}{|c|}{ Means of RP Treatments } \\
\hline & & 85.43 & 88.73 & 87.08 & 13.10 & 13.60 & 13.35 & 5.80 & 6.40 & 6.10 & 4.68 & 5.27 & 4.98 & 4.77 & 5.10 & 4.93 \\
\hline & & 90.73 & 94.53 & 92.63 & 14.27 & 14.93 & 14.60 & 6.97 & 7.77 & 7.37 & 5.96 & 6.60 & 6.28 & 5.51 & 5.68 & 5.59 \\
\hline \multicolumn{2}{|c|}{ L.S.D 0.05} & \multicolumn{3}{|c|}{$\begin{array}{l}\text { I: } 13.5 \text { RP: } 3.90 \quad \text { M: } 2.95 \\
\text { I*PR: n.s I*M: } 15.80 \text { RP*M: } \\
6.20 \text { I*RP*M: } 10.30\end{array}$} & \multicolumn{3}{|c|}{$\begin{array}{l}\text { I: } 4.90 \text { RP: } .90 \quad \text { M: } 0.40 \\
\text { I* PR: } 4.40 \text { I*M: } 4.80 \\
\text { RP*M: } 1.10 \quad \text { I*RP*M: } \\
\text { n.s }\end{array}$} & \multicolumn{3}{|c|}{$\begin{array}{l}\text { I: } 2.20 \text { RP: } 0.90 \mathrm{M}: \\
0.50 \quad \text { I*PR: } 1.90 \quad I^{*} \mathrm{M}: \\
2.30 \mathrm{RP} * \mathrm{M}: 3.30 \\
\text { I*RP*M: } 2.40\end{array}$} & \multicolumn{3}{|c|}{$\begin{array}{l}\text { I: } 1.9 \text { RP:0.96 M: } \\
0.52 \text { I*PR: n.s } \\
\text { I*M:2.26 RP*M: } 0.48 \\
\text { I*RP*M: } 4.15\end{array}$} & \multicolumn{3}{|c|}{$\begin{array}{l}\text { I: } 0.21 \quad \text { RP: } 0.43 \text { M: } \\
0.19 \quad \text { I*PR: } 0.57 \\
\text { I*M: } 0.39 \text { RP*M: } 0.31 \\
\text { I*RP*M: } 0.30\end{array}$} \\
\hline
\end{tabular}

Note: $I_{1}, I_{2}$ and $I_{3}$ : irrigation every 15,21 and 35 days respectively; $\mathrm{RP}_{0}$ and $\mathrm{RP}_{1}$ : non and $16 \mathrm{~kg} \mathrm{P}^{-1}$;

$\mathrm{M}_{0}$ and $\mathrm{M}_{1}$ : non and AMF n.s: non - significant at the $5 \%$ level of probability at L.S.D test. 
Table 4. Wheat yieldas affected by mycorrhizal fungi and rock phosphate under irrigation intervals.

\begin{tabular}{|c|c|c|c|c|c|c|c|c|c|c|c|c|c|}
\hline \multirow{3}{*}{$\begin{array}{l}\text { Irrigation } \\
\text { intervals } \\
\text { (I) }\end{array}$} & \multirow{3}{*}{$\begin{array}{c}\text { Rock } \\
\text { phosphate } \\
(\mathrm{RP})\end{array}$} & \multicolumn{12}{|c|}{ Mycorrhiza (M) } \\
\hline & & $\mathrm{M}_{0}$ & $\mathrm{M}_{1}$ & mean & $\mathrm{M}_{2}$ & $\mathrm{M}_{3}$ & mean & $\mathrm{M}_{2}$ & $\mathrm{M}_{3}$ & mean & $\mathrm{M}_{2}$ & $\mathrm{M}_{3}$ & mean \\
\hline & & \multicolumn{3}{|c|}{$\begin{array}{l}\text { Grain yield } \\
\left(\mathrm{kgha}^{-1}\right)\end{array}$} & \multicolumn{3}{|c|}{$\begin{array}{l}\text { Straw yeild } \\
\left(\mathrm{kgha}^{-1}\right)\end{array}$} & \multicolumn{3}{|c|}{$\begin{array}{l}\text { Biological yield } \\
\left(\mathrm{kgha}^{-1}\right)\end{array}$} & \multicolumn{3}{|c|}{$\begin{array}{l}\text { Harvest index } \\
(\%)\end{array}$} \\
\hline \multirow{2}{*}{$\mathrm{I}_{1}$} & $\mathrm{RP}_{0}$ & 3360.72 & 3785.04 & 3572.88 & 5292.72 & 5767.44 & 5530.08 & 8653.44 & 9552.48 & 9102.96 & 93.21 & 95.10 & 94.15 \\
\hline & $\mathrm{RP}_{1}$ & 3906.72 & 4328.40 & 4117.56 & 6243.12 & 7094.64 & 6668.88 & 10149.84 & 11423.04 & 10786.44 & 92.38 & 90.94 & 91.66 \\
\hline \multicolumn{2}{|c|}{ Mean } & 3633.72 & 4056.72 & 3845.22 & 5767.92 & 6431.04 & 6099.48 & 9401.64 & 10487.76 & 9944.70 & 92.79 & 93.02 & 92.91 \\
\hline \multirow{2}{*}{$\mathrm{I}_{2}$} & $\mathrm{RP}_{0}$ & 3409.92 & 3872.40 & 3641.16 & 6720.96 & 6986.16 & 6853.56 & 10130.88 & 10858.56 & 10494.72 & 80.78 & 85.59 & 83.19 \\
\hline & $\mathrm{RP}_{1}$ & 4127.28 & 4633.44 & 4380.36 & 6961.20 & 7680.24 & 7320.72 & 11088.48 & 12313.68 & 11701.08 & 89.33 & 90.31 & 89.82 \\
\hline \multicolumn{2}{|c|}{ Mean } & 3768.60 & 4252.92 & 4010.76 & 6841.08 & 7333.20 & 7087.14 & 10609.68 & 11586.12 & 11097.90 & 85.06 & 87.95 & 86.50 \\
\hline \multirow{2}{*}{$J_{3}$} & $\mathrm{RP}_{0}$ & 1681.44 & 1920.24 & 1800.84 & 4769.04 & 5640.72 & 5204.88 & 6450.48 & 7560.96 & 7005.72 & 62.56 & 60.95 & 61.76 \\
\hline & $\mathrm{RP}_{1}$ & 1933.92 & 2164.56 & 2049.24 & 5736.00 & 6476.40 & 6106.20 & 7669.92 & 8640.96 & 8155.44 & 60.51 & 60.12 & 60.32 \\
\hline \multicolumn{2}{|c|}{ Mean } & 1807.68 & 2042.40 & 1925.04 & 5252.52 & 6058.56 & 5655.54 & 7060.20 & 8100.96 & 7580.58 & 61.54 & 60.54 & 61.04 \\
\hline \multicolumn{2}{|c|}{ Grand mean } & 3070.00 & 3450.68 & 3260.34 & 5953.84 & 6607.60 & 6280.72 & 9023.84 & 10058.28 & 9541.06 & 79.80 & 80.50 & 80.15 \\
\hline & & \multicolumn{12}{|c|}{ Means of RP Treatments } \\
\hline \multicolumn{2}{|c|}{$\mathrm{RP}_{0}$} & 2817.36 & 3192.56 & 3004.96 & 5594.24 & 6131.44 & 5862.84 & 8411.60 & 9324.00 & 8867.80 & 78.85 & 80.55 & 79.70 \\
\hline \multicolumn{2}{|c|}{$\mathrm{RP}_{1}$} & 3322.64 & 3708.80 & 3515.72 & 6313.44 & 7083.76 & 6698.60 & 9636.08 & 10792.56 & 10214.32 & 80.74 & 80.46 & 80.60 \\
\hline \multicolumn{2}{|c|}{ L.S.D 0.05} & \multicolumn{3}{|c|}{$\begin{array}{l}\text { I*PR: } 193.50 \text { I*M: } 119.90 \text { RP*M: } \\
51.90 \quad \text { I*RP*M:193.70 }\end{array}$} & \multicolumn{3}{|c|}{$\begin{array}{l}\text { I* PR: } 478.90 \text { I*M: } 456.80 \mathrm{RP} * \mathrm{M}: \\
\text { I*RP*M: } 399.00\end{array}$} & \multicolumn{3}{|c|}{$\begin{array}{l}\text { I* PR: } 580.90 \text { I*M: } 460.20 \text { RP*M: } 137.70 \\
\text { I*RP*M: } 659.80\end{array}$} & \multicolumn{3}{|c|}{ I*PR: 9.7 I*M: 12.79} \\
\hline
\end{tabular}

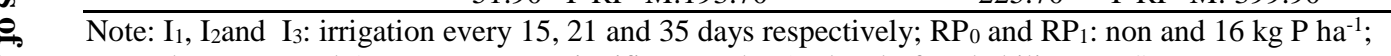


Table 5. NPK contents asaffectecd by mycorrhizal fungi and rock phosphate under irrigation intervals.

\begin{tabular}{|c|c|c|c|c|c|c|c|c|c|c|}
\hline \multirow{3}{*}{$\begin{array}{c}\text { Irrigation } \\
\text { interval } \\
\text { (I) }\end{array}$} & \multirow{3}{*}{$\begin{array}{l}\text { Rock phosphate } \\
\text { (RP) }\end{array}$} & \multicolumn{9}{|c|}{ Mycorrhiza (M) } \\
\hline & & $\mathrm{M}_{0}$ & $\mathrm{M}_{1}$ & mean & $\mathrm{M}_{2}$ & $\mathrm{M}_{3}$ & mean & $\mathrm{M}_{2}$ & $\mathrm{M}_{3}$ & mean \\
\hline & & & $\mathrm{N} \%$ & & & $\mathrm{P} \%$ & & \multicolumn{3}{|c|}{$\mathrm{K} \%$} \\
\hline \multicolumn{11}{|c|}{ Grain } \\
\hline \multirow{2}{*}{$\mathrm{I}_{1}$} & $\mathrm{RP}_{0}$ & 89.10 & 91.80 & 90.45 & 14.90 & 15.10 & 15.00 & 5.90 & 6.40 & 6.15 \\
\hline & $\mathrm{RP}_{1}$ & 93.60 & 96.80 & 95.20 & 15.80 & 16.20 & 16.00 & 7.10 & 7.60 & 7.35 \\
\hline \multicolumn{2}{|c|}{ Mean } & 91.35 & 94.30 & 92.83 & 15.35 & 15.65 & 15.50 & 6.50 & 7.00 & 6.75 \\
\hline \multirow{2}{*}{$\mathrm{I}_{2}$} & $\mathrm{RP}_{0}$ & 97.00 & 97.90 & 97.45 & 15.30 & 15.90 & 15.60 & 7.20 & 7.80 & 7.50 \\
\hline & $\mathrm{RP}_{1}$ & 99.30 & 102.10 & 100.70 & 16.10 & 16.80 & 16.45 & 8.20 & 9.70 & 8.95 \\
\hline \multicolumn{2}{|c|}{ Mean } & 98.15 & 100.00 & 99.08 & 15.70 & 16.35 & 16.03 & 7.70 & 8.75 & 8.23 \\
\hline \multirow{2}{*}{$\mathrm{I}_{3}$} & $\mathrm{RP}_{0}$ & 70.20 & 76.50 & 73.35 & 9.10 & 9.80 & 9.45 & 4.30 & 5.00 & 4.65 \\
\hline & $\mathrm{RP}_{1}$ & 79.30 & 84.70 & 82.00 & 10.90 & 11.80 & 11.35 & 5.60 & 6.00 & 5.80 \\
\hline \multicolumn{2}{|c|}{ Mean } & 74.75 & 80.60 & 77.68 & 10.00 & 10.80 & 10.40 & 4.95 & 5.50 & 5.23 \\
\hline \multicolumn{2}{|c|}{ Grand mean } & 88.08 & 91.63 & 89.86 & 13.68 & 14.27 & 13.98 & 6.38 & 7.08 & 6.73 \\
\hline & & \multicolumn{9}{|c|}{ Means of RP Treatments } \\
\hline \multicolumn{2}{|c|}{$\mathrm{RP}_{0}$} & 85.43 & 88.73 & 87.08 & 13.10 & 13.60 & 13.35 & 5.80 & 6.40 & 6.10 \\
\hline \multicolumn{2}{|c|}{$\mathrm{RP}_{1}$} & 90.73 & 94.53 & 92.63 & 14.27 & 14.93 & 14.60 & 6.97 & 7.77 & 7.37 \\
\hline \multicolumn{2}{|l|}{ L.S.D 0.05} & I: $0.01 \quad$ RP: $n . s$ & M: 0.01 & I*PR: & I: $1.51 \quad$ RP: n.s & M: 1. & & I: 0.09 & RP: n.s 1 & \\
\hline \multicolumn{11}{|c|}{ Srtraw } \\
\hline \multirow{2}{*}{$\mathrm{I}_{1}$} & $\mathrm{RP}_{0}$ & 4.90 & 5.50 & 5.20 & 5.01 & 5.39 & 5.20 & 5.01 & 5.39 & 5.20 \\
\hline & $\mathrm{RP}_{1}$ & 6.60 & 7.30 & 6.95 & 5.61 & 6.02 & 5.82 & 5.61 & 6.02 & 5.82 \\
\hline \multicolumn{2}{|c|}{ Mean } & 5.75 & 6.40 & 6.08 & 5.31 & 5.71 & 5.51 & 5.31 & 5.71 & 5.51 \\
\hline \multirow{2}{*}{$\mathrm{I}_{2}$} & $\mathrm{RP}_{0}$ & 5.84 & 6.51 & 6.18 & 5.12 & 5.51 & 5.32 & 5.12 & 5.51 & 5.32 \\
\hline & $\mathrm{RP}_{1}$ & 6.97 & 7.80 & 7.39 & 6.13 & 6.20 & 6.17 & 6.13 & 6.20 & 6.17 \\
\hline \multicolumn{2}{|c|}{ Mean } & 6.41 & 7.16 & 6.78 & 5.63 & 5.86 & 5.74 & 5.63 & 5.86 & 5.74 \\
\hline \multirow{2}{*}{$\mathrm{I}_{3}$} & $\mathrm{RP}_{0}$ & 3.30 & 3.80 & 3.55 & 4.17 & 4.39 & 4.28 & 4.17 & 4.39 & 4.28 \\
\hline & $\mathrm{RP}_{1}$ & 4.30 & 4.70 & 4.50 & 4.78 & 4.81 & 4.80 & 4.78 & 4.81 & 4.80 \\
\hline \multicolumn{2}{|c|}{ Mean } & 3.80 & 4.25 & 4.03 & 4.48 & 4.60 & 4.54 & 4.48 & 4.60 & 4.54 \\
\hline \multicolumn{2}{|c|}{ Grand mean } & 5.32 & 5.94 & 5.63 & 5.14 & 5.39 & 5.26 & 5.14 & 5.39 & 5.26 \\
\hline & & & & & Means of RI & Treatn & & & & \\
\hline \multicolumn{2}{|c|}{$\mathrm{RP}_{0}$} & 4.68 & 5.27 & 4.98 & 4.77 & 5.10 & 4.93 & 4.77 & 5.10 & 4.93 \\
\hline \multicolumn{2}{|c|}{$\mathrm{RP}_{1}$} & 5.96 & 6.60 & 6.28 & 5.51 & 5.68 & 5.59 & 5.51 & 5.68 & 5.59 \\
\hline \multicolumn{2}{|l|}{ L.S.D 0.05} & $\begin{array}{l}\text { I: } 0.09 \text { RP: n.s } \\
\text { I*PR: n.s I*M: } \\
\text { I*RP*M: } 0.34\end{array}$ & $\begin{array}{l}\text { M: } 0.11 \\
.26 \text { RP*M: } 0.16\end{array}$ & & $\begin{array}{l}\text { I: } 0.09 \text { RP: n.s } \\
\text { I*PR: n.s I*M: } \\
\text { I*RP*M: } 0.34\end{array}$ & $\begin{array}{r}\text { M: } 0 . \\
.26 \mathrm{RP}\end{array}$ & & $\begin{array}{l}\text { I: } 0.09 \\
\text { I*PR: r } \\
\text { I*RP*I }\end{array}$ & $\begin{array}{l}\text { RP: n.s I } \\
\text { s I*M: } 0.2 \\
0.34\end{array}$ & 1: 0.16 \\
\hline
\end{tabular}

$\mathrm{M}_{0}$ and $\mathrm{M}_{1}$ : non and AMF n.s: non - significant at the $5 \%$ level of probability at L.S.D test. 


\section{References}

Aissa E.; Mougou, K. and Khalfalla, K. 2016. Influence of mycorrhizal inoculation and source of phosphorous on growth and nutrient uptake of pepper (Capsicum annuum L.) in calcareous soil. J. of New Sci., Agric. and Biotechnol. 28(5): 15891595.

Alizadeh, O.; Zare, M. and Nasr,A. H.2011. Evaluation effect of mycorrhiza inoculate under drought stress condition on grain yield of sorghum. (Sorghum bicolor). Adv. Environ. Biol. 5(8):23612364.

Al-Karaki, G. N. and Al-Raddad, A. 1997. Effects of arbuscular mycorrhizal fungi and drought stress on growth and nutrient uptake of two wheat genotypes differing in drought resistance. Mycorrhiza 7:83-88.

Al-Karaki, G. N. and Clark, R. B. 1998. Growth, mineral acquisition, and water use by mycorrhizal wheat grown under water stress. J. Pl. Nutr. 21:263-276.

Arab, A.; Baradran, R. and Vahidipour, T. H. 2013. Effect of irrigation and mycorrhizal biofertilizers on yield and agronomic traits of millet (panicummili aceum L.)Inter. J. of Agric. and Crop Sci. 6(2):103-109.

Artursson, V.; Finlay, R. D. and Jansson, J. 2006. Interactions between arbuscular mycorrhizal fungi and bacteria and their potential for stimulating plant growth. Env. Microbiol. 8:1-10.

Auge, R.M.2001.Water relations, drought and vesicular-arbuscularmycorrhiza symbiosis.Mycorrhiza 11: 3-42.

Aziz, M. A.; Sallam, M. F.; El-Gendy,A. M. and Abd El-Moniem., A. 1999. Some physical and hydrological properties of sandy soils of Inshas as affected by conditioning and irrigation conditions. Egypt, J. Soil Sci. 39(4):531-559.

Boland, N. S.; Naidu, R.; Mahimairaja, S.and Baskaran, .1994. Influence of low molecular weight organic acids on the solubilization of phosphates. Biology and fertility of soils (18): 311-319.

Bucher, M. (2007) Functional biology of plant phosphate uptake at root and mycorrhiza interfaces. New Phytol 173:11-26.

Cabala-Rosand, P. and Wild, A. 1982. Direct use of low gradephosphate rock from Brazil as fertilizer. II. Effects of mycorrhizal inoculation and nitrogen source. Pl. Soil 65:363-373.

Chapman, H. D. and Pratt, P. F. 1961. Methods of analysis for soil, plant and water. DIV. Agric. Sci., Univ. of Calif.

El-Far, I. A. and Teama, E. A. 1999. Effect of irrigation intervals on productivity and quality of some bread and durum wheat cultivars. Assiut J. Agric. Sci. 30(2): 27-38.

El-Maddah, E. I.; El-Sodany, M. El-D. and Mahmoud, A. A. 2012. Effect of irrigation intervals, phosphorus levels and antioxidants of foliar ascorbic and citric acid (ASCOBIN) application on maize and wheat crops and some soil properties. J. Soil Sci. and Agric. Eng., Mansoura Univ., 3 (1): 63 - 93.

El-Maghraby, S. E. 1997. Impact of natural conditioners and saline irrigation water frequency of calcareous soil productivity. Egypt. J. Soil Sci. 37(2): 267-281.

El-Sersawy, M. M.; Bouthaina., F.; Abd ElGhanyand Baresoum., M. S. 1993. Effects of manuring, fertilization and irrigation on soil physical, microbiological properties and sunflower production in the north-western coastal zone of Egypt. Desert Inst. Bull., Egypt, (43) 2:7390.

El-Sherbiny, W. A. 2002. A study on some management practices in calcareous soils and their reflection on soil physical, mechanical properties and crop production. Ph.D. Fac. of Agric. Benha Univ. Egypt.

Elwan, L. M. 2001.Effect of soil water regimes and inoculation with mycorrhizae on growth and nutrients content of maize plants. J. Agric. Res., 28: $163-172$.

Ghaly, N. G. and El-Sodany, M. El-D. 2009. Effect of irrigation intervals and active dry yeast foliar application on nigella sativa 1. plant and some soil properties at El-Gharbia governorate. Egypt. J. of Appl. Sci., 24(5):249-272.

Ghorbanian, D.; Haratyuny, S.; Mazaheri, D. and Rejali, F. 2011. Effects of mycorrhizal symbiosis and different levels of phosphorous on yield, micro and macro elements of zea maize L. under water stress condition. African J. of Agric. Res. 6 (24): 5481-5489.

Gomaa, M. A.; Radwan, F. I.; Rehab,I. F.; Kandil, E. E. and Abd El-Kawy, A. R. M. 2015. Response of maize to compost and A. mycorrhizal under condition of water stress. Inter. J. of Environ (4): 271-277.

Grant, C.; Bittman, S.; Monteal, M.; Plenchetle, C. and More, C. 2004. Soil and fertilizer phosphorous: Effects on plant $\mathrm{P}$ supply and mycorrhizal development. Candian J. of Pl. Sci. 85:3-14.

Harrier, L. A. 2001. The arbuscular mycorrhizal symbiosis a molecular review of the fungal dimension. J. Exp. Bot. 52:469-478.

Harvey, M. M. 2012. Effect of different soil managements on some chemical and physical properties of El-Nubaria soils. Ph.D. Faculty of Agriculture Benha Univ., Egypt.

Harvey, M. M.; A.El-Kotb, H. M. and El-Edfawy, Y. M. 2015. Effectoforganic, bio and inorganic phosphorous fertilizerons oil physical properties and fababean productivity under tillage systems in calcareous soil. Inter. J of Acad. Res. 7(4):149156.

Hashem, F. A. 1996. Improving calcareous soil productivity under saline water irrigation using amendments and bio-fertilizer. Annals of Agric. Sci. Moshtohor. (34): 1943- 1955.

Jackson, M. L. 1973. Soil chemical analysis. Prentice-Hall, Englewood Cliffs. New Jersey.

Karandashov, V. and Bucher, M. 2005. Symbiotic phosphate transport in arbuscular mycorrhizas. Trends Pl. Sci. 10(1):22-29.

Klute, A. 1986. "Methods of soil analysis part I. physical and mineralogical methods". 2nd ed., Agron. Madison, Wisconsin, U.S.A.

Kucey, R. M. N. and Bole, J. B. 1984. Availability of phosphorus from rock phosphates in moderately and weakly acidic soils as determined 
by dilution, a value and total $\mathrm{P}$ uptake methods. Soil Sci. 138:180-188.

Kumar, A.; Choudhary, A. K. and Suri, V. K. 2016. Influence of AM fungi, inorganic phosphorus and irrigation regimes on plant water relations and soil physical properties in okra (Abelmoschus esculentus L.) - pea (Pisums ativum L.) cropping system in Himalayan acid alfisol. J. Pl. Nutr. 39 (5): 666-682

Little, T. M. and Hills, F. J. 1978.Design and analysis. P:115-124 John wiky and sons. New Youk. USA.

Marchner, H. and Dell, B. 1994. Nutrient uptake in microhizal symbiosis In Robson, A. d., Abott and Malaccjuk, N, eds. P. 89-102. Mangement of mycorrhizal in agriculture Hortculture and Forestry Netherlands: Acad. Publishers (Eds).

Miransari, M. 2010. Contribution of arbuscular mycorrhizal symbiosis to plant growth under different types of soil stresses. Review article. Pl. Biol. 12: 563-569.

Mohsen, T.; Zanghami, R.; Boojar, M. M. S. and Oveysi, M. 2012. Effect of drought stress and different nitrogen levels on morphological traits of proline in leaf and protein of corn grain (Zea mays, L.) .American Eurasin. J. Agric., and Environ. Sci., 21(1):49-56.

Munns, R. 2002. Comparative physiology of salt and water stress. Pl. Cell Environ 25: 239-250.

Page, A. L.; Miller, R. H.andKeeny, D. R. 1982. "Methods of soil analysis part II: chemical and microbiological properties. 2nd Ed. Am. Soc. Agron. Madison, Wisconsin, U.S.A.

Porcel, R.; Barea, J. M. and Ruiz-Lozano, J. M. 2003. Antioxidant activities in mycorrhizal soybean plants under drought stress and their possible relationship to the process of nodule senescence. New Phytol. 157:135-143.

Powell, C. L. 1979. Effect of mycorrhizal fungi on recovery of phosphate fertilizer from soil by ryegrass plants. New Phytol. 83:681-694. Press, Inc. U.S.A. pp 311-324.

Richardson, A. E; Barea, J. M; McNeill, A. M. and Prigent-Combaret, C. 2009. Acquisition of phosphorus and nitrogen in the rhizosphere and plant growth promotion by microorganisms. Pl. Soil 321:305-339

Rillig, M. C. and Mummey, D. L. 2006. Mycorrhizas and soil structure. New Phytol. 171:41-53.

Schussler, A.; Schwarzott, D. and Walker, C. 2001. A new fungal phylum, the Glomeromycota: phylogeny and evolution. Mycol. Res.105:14131421.

Shenoy, V. V. and Kalagudi, G. M. 2005. Enhancing plant phosphorus use efficiency for sustainable cropping. Biotechnol. Adv. 23:501-513.

Singh, S.; Mishra, R.; Singh, A.; Ghoshal, N. and Singh, K. P. 2009. Soil physicochemical properties in a grassland and agroecosystem receiving varying organic inputs. Soil Sci. Soc. Am. J. 73(5):1530-1538.

Smith, S. E. and Read, D. J. 2008. Mycorrhizal symbiosis, 3rd Ed., Academic Press, San Diego, CA.

Soha, E. K. and Yousef, R. M. M. 2014. Interaction effects of different soil moisture levels, arbuscular mycorrhizal fungi and three phosphate levels on growth yield and photosynthetic activity of garden cress (Lepidiums ativum L.) pl. Inter. J. of Adv. Res.(2) 6: 723-737.

Subramanian,K. S. and Charest, C. 1997. Nutritional, growth, and reproductive responses of maize (Zea mays L.) to arbuscular mycorrhizal inoculation during and after drought stress at tasselling. Mycorrhiza 7:25-32.

Sultani, M. I.; Gill, M. A.; Anwar, M. M. and Athar, M. 2007. Evaluation of soil physical properties as influenced by various green manuring legumes and phosphorus fertilization under rain fed conditions. Int. J. Environ. Sci. Tech. 4 (1): 109-118

Sylvia, D. M; Hammond; L. C.; Bennett, J. M.; Haas, J. H. and Linda, S. B.1993. Field response of maize to a VAM fungus and water management. Agron. J. 85:193-198.

Waidyanatha, U. P.; Yogaratnam, N. and Ariyaratne, W. A. 1979. Mycorrhizal infection on growth and nitrogen fixation of Pueraria and Stylosanthes and uptake of phosphorus from two rock phosphates. NewPhytol. 82:147-152.

Wilson, G. W. T.; Rice, C. W; Rillig, M. C.; Springer, A. and Hartnett, D. C. 2009. Soil aggregation and carbon sequestration are tightly correlated with the abundance of arbuscular mycorrhizal fungi: Results from long-term field experiments. Ecol. Lett. 12(5):452-461.

Zaki, R. M. and Radwan, T. E. E. 2006. Impact of micro organisms activity on phosphorus availability and its uptake by fababean plants grown on some newly reclaimed soils in Egypt. Inter. J. of Agric. \& Bio. (2): 221-225.

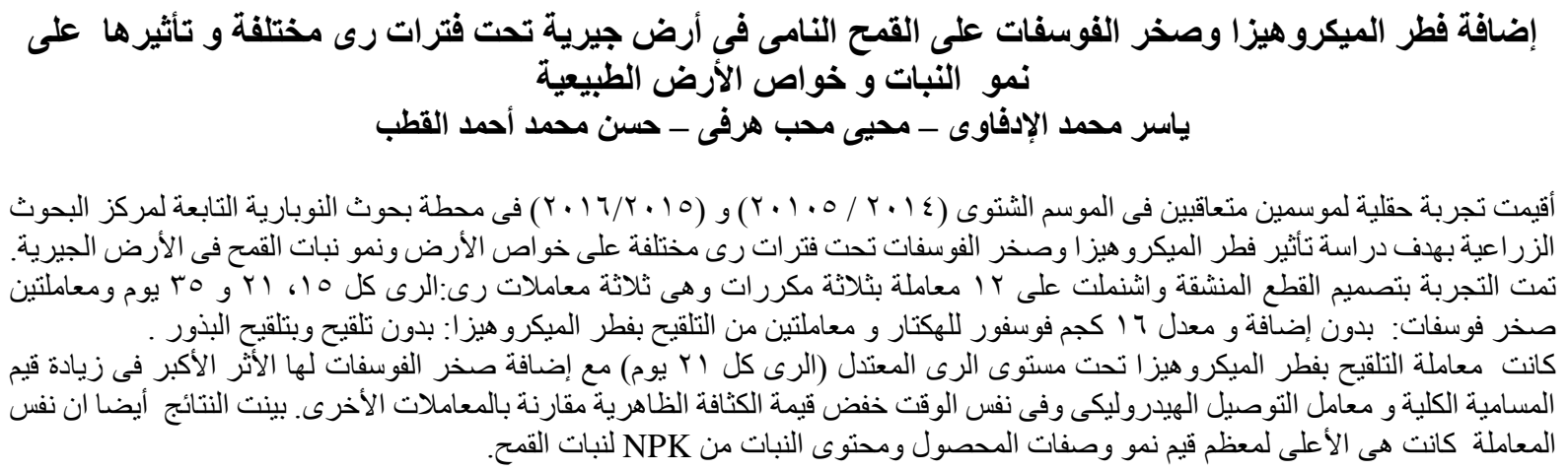

